\title{
Удалова А.Э.
}

\section{Гражданско-правовое воспитание в современной начальной школе в соответствии с ФГОС начального общего образования}

ГАОУ ВО Московский городской педагогический университет Институт среднего профессионального образования имени К.Д. Ушинского учебный корпус «Колледж имени С.Я. Маршака»

(Россия, Москва)

doi: 10.18411/lj-01-2019-35

idsp: ljournal-01-2019-35

\section{Аннотация}

В данной статье рассматриваются вопросы организации и реализации основных направлений гражданско-правового воспитания младших школьников. Даны определения гражданского и правового воспитания учащихся начальной школы. В статье отмечены проблемы гражданско-правового воспитания учащихся начальной школы и пути их решения.

Ключевые слова: гражданское и правовое воспитание; государство; гражданин; права и обязанности; свобода и ответственность младшего школьника; формы и методы гражданско-правового воспитания; гуманизм; толерантность; коммуникабельность.

\section{Abstract}

This article deals with the organization and implementation of the main directions of civil law education of younger students. The definitions of civil and legal education of elementary school students are given. The article points out the problems of civil-law upbringing of primary school students and the ways to solve them.

Keywords: civil and legal education; state; citizen; rights and obligations; the freedom and responsibility of the younger student; forms and methods of civil law education; humanism; tolerance; sociability.

Гражданско-правовое воспитание в современной начальной школе представляет собой целенаправленную деятельность по передаче знаний, и формированию навыков в области гражданственности и права от одного поколения к другому. К ним относятся: правовые идеалы, как основа гражданского общества; действующее законодательство; способы защиты прав и свобод; механизм разрешения конфликтов и юридическая практика с учетом возрастных особенностей. Гражданско-правовое воспитание призвано формировать у детей не только высокий уровень гражданской ответственности и правосознания, но и формирующуюся на этой основе правовую культуру. В настоящее время, гражданско-правовое воспитание подрастающего поколения стало особенно актуальным. Быть истинным гражданином, патриотом своей страны, значит заниматься созидательным трудом, стремиться к ее развитию и процветанию, быть готовым отстаивать ее интересы. Такие глобальные цели стоят перед современной системой воспитания [см., например 8, с. 157]. Соответственно, их реализация, требует преобразования форм и методов воспитательного воздействия, использования современных технологий, нуждается в создании нового подхода к данному вопросу, согласно которому, гражданско-правовое воспитание, рассматривается как один из важных компонентов развития современного общества [7, с. 33 и след.]. Ученые считают, что основная задача по гражданско-правовому воспитанию младших школьников - это признание того факта, что ребенок (индивид) является полноценной и полноправной личностью, знающей свои права и обязанности, правила поведения в обществе, которым их обязаны научить семья, школа и общество. 
Мало того, они уже обязаны защитить и отстоять, законным способом, эти права [см., подробнее 6, с. 38-39].

Педагоги, ученые и юристы рекомендуют всю работу по гражданскому и правовому воспитанию - разделить на три этапа:

1. Работа с педагогическим коллективом школы, так как от подготовки педагогических кадров, прежде всего, зависит успех, и качество этой деятельности.

2. Работа с родителями учеников по повышению их гражданско-правовой культуры. Так как правовая неграмотность родителей часто приводит к серьезным конфликтам.

3. Работа с младшими школьниками на уроках и во внешкольных мероприятиях, направленная на правильное восприятие окружающей среды, социума и права.

Практика показывает, что далеко не все школьники 1-4 классов, могут ответить на вопросы: В какой стране ты живешь? Каковы твои права и обязанности? Что такое «Конвенция о правах ребенка» и многое другое. Это свидетельствует о том, что правовая культура учащихся находится на низком уровне.

Важной задачей правового воспитания учащихся начальной школы является формирование правовой культуры, как многогранность установок личности, убеждений, правовых знаний, реализуемых в процессе обучения и воспитания. Известные в этой научной области исследователи, такие как В.И. Каминская и А.Р. Ратинов, одними из первых анализировали эту проблему, определяя правовую культуру как «систему овеществленных и идеальных элементов, относящихся к сфере действия права, их обращения в сознании и поведении людей» [3].

Е.М. Кропанева в своих работах говорит о том, что «Многообразие правовых знаний создает условия для выделения их разных видов» [4, с. 39]. Она выделяет общетеоретические правовые знания, в основе которых - закон; правовые нормы как система абстрактных правовых категорий; знания о системах деятельности в правовой сфере; знания о правовой деятельности, полученные эмпирическим путем; оценочные правовые знания; учебные правовые знания - с которыми в основном имеют дело учителя и обучаемый. Учебные правовые знания, также имеют собственную классификацию. Особый вид правовых знаний, по мнению Е.М. Кропаневой, составляют исторические и правовые знания об историко-правовой культуре народов, о процессе возникновения и развития права [4, с. 40].

Современный школьник постоянно находится перед проблемой выбора возможного решения различных ситуаций, предпочтения определенного варианта поведения, выбор которого напрямую зависит от уровня его правовой культуры. В соответствии с Приказом Минобрнауки России от 06 октября 2009 г. № 373 «Об утверждении и введении в действие федерального государственного образовательного стандарта начального общего образования» [3] (далее по тексту ФГОС НОО), обучение и воспитание в начальной школе направлено на развитие у учащегося познавательных способностей, выработку навыков активного овладения учебным материалом. Такой подход позволяет объединить знания в целостную систему, направленную на осознанное восприятие окружающего мира. Овладение различными способами работы с учебным материалом, развитие мышления, так же оказывает прямое влияние на усвоение детьми нравственных знаний и накопления правового опыта.

Кроме того, в характеристике выпускника начальной школы по ФГОС НОО, представлены следующие ориентиры: Любить свою Родину, свой край, свой народ, быть готовым и самостоятельно действовать и отвечать за свои поступки перед семьей и обществом; уметь обосновывать свою позицию, высказывать свое мнение; выполнять правила здорового и безопасного для себя и окружающих образа жизни. Таким образом, формирование основ гражданско-правовых знаний, представляет собой поэтапный, целостный, непрерывный процесс, включенный в образовательную среду. Неотъемлемой частью этой среды является педагогика как наука о воспитании, высокая 
и вечная задача которой, состоит в воспитание умного, доброго, сильного и честного, любознательного и творческого человека.

Младший школьный возраст - это активный период формирования личности человека, его духовности, нравственности, ответственности. Это период воспитания ребенка в духе толерантности, мира, уважения к правам и свободам человека, равенства и равных возможностей в развитии личности.

Таким образом, можно сделать вывод, что важнейшей целью гражданскоправового развития и воспитания младших школьников является формирование правосознания и правовой культуры обучающихся, воспитание их в духе патриотизма и гражданственности. Соответственно, правовое воспитание младших школьников не является самостоятельной дисциплиной, оно органично входит в процесс нравственного воспитания детей и приобретения ими норм поведения в школьном коллективе и в обществе. В частности, ученики младших классов должны познакомиться с правами, предусмотренными российскими и международными нормативными актами, например: Конституцией Российской Федерации; Федеральным закон от 24 июля 1998 г. № 124-Ф3 «Об основных гарантиях прав ребенка в Российской Федерации» [1]; Всеобщей декларацией прав человека принятой Генеральной ассамблеей ООН 10 декабря 1948 г., Конвенцией о правах ребенка, одобренной Генеральной Ассамблеей ООН 20 ноября 1989 г. [5, с. 39-44; с. 306-324]. Учащиеся обязаны уважительно относиться к законам страны и знать твердо, что их нельзя никому нарушать.

Учащимся начальной школы необходимо знать о том, что:

— каждый человек должен соблюдать законы государства, и знать, что это его обязанность;

— каждый человек нашей страны является ее гражданином и живет в государстве, которое его защищает;

— если человек нарушает закон, то он несет за это ответственность;

- каждый человек равен перед законом и у него есть право (на жизнь, жилище, свободу перемещения, образование, свободу слова, отдых и т.д.).

В процессе работы, направленной на формирование правовой культуры у младших школьников, должны решаться следующие задачи:

- воспитывать гражданские чувства детей, уважение к своим родителям, учителям, окружающим людям;

- воспитывать личность, правильно воспринимающую окружающую среду, осознающую достоинства человека, формировать толерантность;

- формировать гражданскую позицию учащегося - «Я россиянин»;

- развивать познавательные интересы, потребности в изучении культурноисторических традиций родного края, города, поселка и других народов;

- формировать умения не создавать конфликты, а при их наличии, уметь разрешать их законным путем;

— формировать уважительное отношение к здоровью и жизни окружающих людей.

В качестве методов гражданско-правового воспитания, необходимо использовать все виды педагогического воздействия: - беседу, игру, внушение, убеждение, поощрение и личный пример. Формы гражданско-правового воспитания могут быть также очень многообразными - это занятия, экскурсии, презентации, просмотр видеороликов, показы учебных и художественных фильмов. Особая роль в этой работе отведена внеурочной деятельности младших школьников, которая является составной частью образовательного процесса по ФГОС НОО. Правовое просвещение, правовая компетентность, цели и задачи, содержание и формы работы по правовому просвещению, детские общественные объединения и организации как форма правового 
просвещения. Внешкольные занятия могут проходить в форме конкурсов, викторин, деловых игр, квестов, с использованием современных информационных технологий, что создает неограниченные возможности для полноценного восприятия информации. Например, ознакомление с красочным содержанием «Конвенции о правах ребенка» и других подобных документов.

Гражданско-правовое воспитание младших школьников должно проходить в доброжелательной, доверительной и главное, в доступной и понятной для детей форме, и обстановке. Ведь, младший школьный возраст - это лучшее время для ознакомления с социальными и нравственными нормами, формирования позитивных социальных установок. Дети хорошо знакомы с таким понятием как правила поведения, которые регулируют их жизнедеятельность в школе, поэтому они способны объективно оценивать поступки своих одноклассников. Но результаты своего поведения не всегда поддаются детскому самоанализу. Следовательно, важно научить воспитанников сравнивать и рационально анализировать, именно, свое поведение. В этом процессе огромную роль играет авторитет учителя, который в начальных классах еще очень высок, дети открыты, склонны к подражанию, стремятся к новому знанию, и поэтому, быстро усваивают гражданско-правовые знания и учатся правильно вести себя в правовой ситуации.

Важно, чтобы ребенок уже с первых самостоятельных поступков, которые он делает осознанно, выбирал способы поведения на основе знания норм права. Овладение правовыми знаниями способствует накоплению опыта добрых поступков и дел, гуманных отношений со сверстниками и взрослыми [9, с. 71-72].

Приобретение гуманистических ценностных ориентаций будет способствовать формированию у младших школьников таких качеств личности, как целеустремленность, ответственность, справедливость, жизнестойкость. Будет формироваться чувство собственного достоинства, уважения к себе и окружающим.

Гражданско-правовое воспитание младших школьников имеет важную практическую направленность, так как способствует их адаптации к новым формам жизнедеятельности и к новым социальным ролям.

Современная школа ставит перед собой задачу обучать гражданско-правовой культуре, как учащихся, так и их родителей. Учитель должен формировать уважение к закону, гражданским правам, проявлять толерантность и способность к компромиссам, уметь создавать благоприятную обстановку, в которой ребенок чувствует себя личностью с ее индивидуальностью и неприкосновенностью. Учащихся надо знакомить с механизмом правового регулирования общественной и личной жизни, их правами и обязанностями, учреждениями, в которые они могут обратиться в случае нарушения их законных прав. Гражданско-правовое воспитание учащихся младшей школы повышает их общественную активность, укрепляет гражданскую позицию.

Роль гражданско-правового воспитания младших школьников трудно переоценить в современном обществе. Сегодня необходимо воспитывать не только образованного человека, но и гражданина, имеющего четкое представление о гражданско-правовых нормах и нравственных общественных ценностях. Так как уровень правовой и нравственной культуры граждан, определяет будущее страны.

$$
* * *
$$

1. Федеральный закон от 24 июля 1998 г. № 124-ФЗ (в ред. от 27 декабря 2018 г.) «Об основных гарантиях прав ребенка в Российской Федерации» // Собрание законодательства РФ. - 1998. - № 31. - Ст. 3802.

2. Приказ Минобрнауки России от 06 октября 2009 г. № 373 (в ред. от 31 декабря 2015 г.) «Об утверждении и введении в действие федерального государственного образовательного стандарта начального общего образования» // Бюллетень нормативных актов федеральных органов исполнительной власти. -2010 . - № 12. 
3. Каминская В.И., Ратинов А.Р. Правосознание как элемент правовой культуры // Правовая культура и вопросы правового воспитания. Сборник научных трудов. - М.: Изд-во Всесоюз. ин-та по изуч. причин и разраб. мер предупреждения преступности, 1974. - 202 с. С. 39-67.

4. Кропанева Е.М. Теория и методика обучения праву: Учеб. пособие. - Екатеринбург: Изд-во Рос. гос. проф. - пед. ун-та, 2010. - 166 с.

5. Международные акты о правах человека. Сборник документов // составители В.А. Карташкин, Е.А. Лукашева - М.: Издательство НОРМА (Издательская группа НОРМА-ИНФРА-М), 2000, - 784 с.

6. Подласый И.П. Педагогика: учебник для бакалавров / И.П. Подласый. - 2-е изд., перераб. и доп. М.: Издательство Юрайт; ИД Юрайт, 2012. - 574 с.

7. Симонова М.М., Удалов Д.Э. Правовые основы патриотического воспитания в Российской Федерации // Наука и школа. 2017. № 2. С. 32-36.

8. Тенчурина Л.З., Удалов Д.Э. Правовые основы экологического воспитания и воспитательный потенциал экологического туризма // Известия международной академии аграрного образования. 2017. № 36. С. 156-159.

9. Удалов Д.Э. Правовое регулирование общественных отношений с участием несовершеннолетних лиц (на примере туристских отношений) // Научный вестник МГИИТ. 2018. № 5 (55). С. 71-77. 